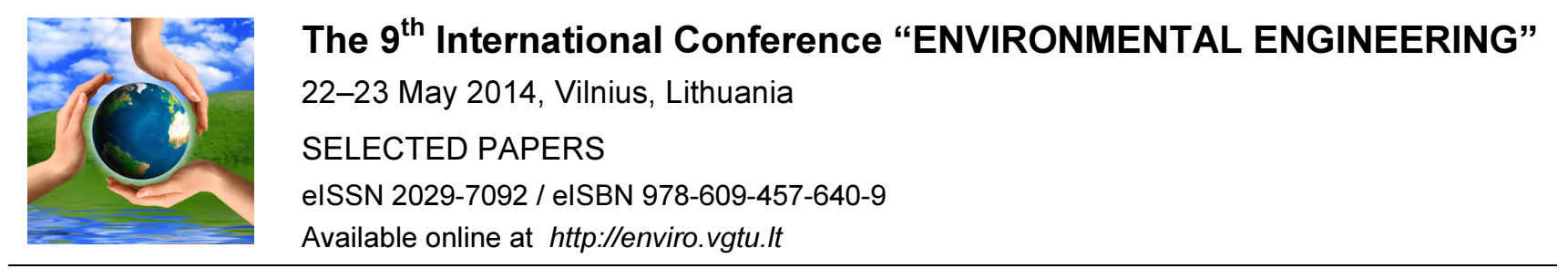

Section: Energy for Buildings

\title{
Multi-objective optimization of shading solutions for a standard family house under Lithuanian conditions
}

\author{
Vilune Lapinskiene, Violeta Motuziene, Vytautas Martinaitis \\ Vilnius Gediminas Technical University, Saulètekio al. 11, 10223 Vilnius, Lithuania
}

\begin{abstract}
Energy efficiency and high indoor quality have become equally important key targets in building design. On the one hand, here passive solar design techniques can successfully take advantage of building site and climate. But on the other hand - most of the shading gives not just positive effects on summer comfort, but at the same time negatively effects heating and lighting energy consumption. This paper aims to investigate the potential of certain shading solutions, their appliance and regulation modes on building annual energy demand and comfort parameters, in order to find the optimal shading. For a case study one-storey standard family house in Lithuania and 20 shading solutions for it have been modelled. The combination of energy simulation program DesignBuilder and decision-making software, based on Analytic Hierarchy Process, have been used. As the result, the external blinds, operating according to the fixed room temperature appeared be the optimal solution for the analyzed family house. The research process had showed, that because of conflicting expert goals and varying criteria values, the optimal shading solution can't be properly chosen without incorporation of decision making process.
\end{abstract}

Keywords: shading; energy; comfort; DesignBuilder; Analytical Hierarchy Process (AHP).

\section{Introduction}

The European energy policy has a clear orientation towards the preservation of energy and the improvement of indoor environmental quality in buildings through the adoption of the European Commission's (EC) Energy Performance of Buildings Directive (EPBD) 2010/31/EU [1], [2].

Buildings' energy efficiency and environmental burden are treated differently in the design and operational phase [2]. During the conceptual design stage of a building, the design team often has to make critical decisions with significant impact on the energy performance and indoor comfort conditions. Here the design and selection of facades, fenestration systems and their control plays a key role. Driven by technological advances in transparent building facades, design alternatives have shifted to utilizing dynamic fenestration and shading systems for optimal control of day lighting and solar gains [3].

Thus, the biggest challenge is to optimize the building design, choosing specific architectural solutions [4], [5], efficient thermal-optical glazing properties and appropriate shading devices [6] suitable for a certain climate.

Most of the design problems involve several conflicting aspects or criteria that the designer tries to improve simultaneously. The final result is a compromise, where human judgment and decision-making is involved [6]. In other words, the decision maker is facing the challenge to solve a multi objective optimization problem. Although the common practice usually employs other methods like simulation and multiple criteria decision analysis techniques that exploit possibly many but in any case limited alternative options [7].

Multicriteria or multi - objective optimization provides a valuable tool for the designer (or decision-maker) to find the best compromise solutions and to get quantitative information on the rate of conflict of the criteria [8].

[9] used a genetic optimization approach for the design of an external shading device in an office with different glazing characteristics. Evolutionary [10] and genetic algorithms [11] have been coupled with building simulation programs to optimize building design.

The AHP (Analytical Hierarchy Process) is one of the suggestions for solutions concerning the construction and application of multi-criteria evaluation systems. The AHP can be defined as a process of hierarchizing a system in order to carry out a wide-ranging evaluation and final selection of one of the alternative solutions to a particular problem. The

Corresponding author: Vilune Lapinskiene. E-mail address: vilune.lapinskiene@vgtu.lt

http://dx.doi.org/10.3846/enviro.2014.269

(C) 2014 The Authors. Published by VGTU Press. This is an open-access article distributed under the terms of the Creative Commons Attribution License, which permits unrestricted use, distribution, and reproduction in any medium, provided the original author and source are credited. 
method can also be understood more broadly as a theory of measurement using quantitative and/or qualitative data [12]. The AHP have been used for life-cycle analysis [13], to evaluate the system intelligence, to estimate the impact of buildings design solutions on building life- cycle and etc.

The current research aims to find the optimal building shading solution for energy efficient house, built in Lithuanian and similar climate conditions, in order to optimize energy and comfort criteria.

\section{Methodology}

Here energy simulation program DesignBuilder is used to define buildings annual energy demand for heating, lighting and auxiliary HVAC energy as well as to simulate comfort. Cooling energy is not simulated, since it is more reasonable to avoid cooling demand with application of passive solar shading measures. When applying certain shading and its control type, different effects are made on energy demand and comfort. Most of the shading gives not just positive effects on summer comfort, but also negative effects on heating energy and lighting energy. Therefore to find the optimal solution, a decisionmaking software [14], based on Analytic Hierarchy Process have been employed. The presented flowchart (Fig. 1) introduces the methodology, instruments and basic steps to follow.

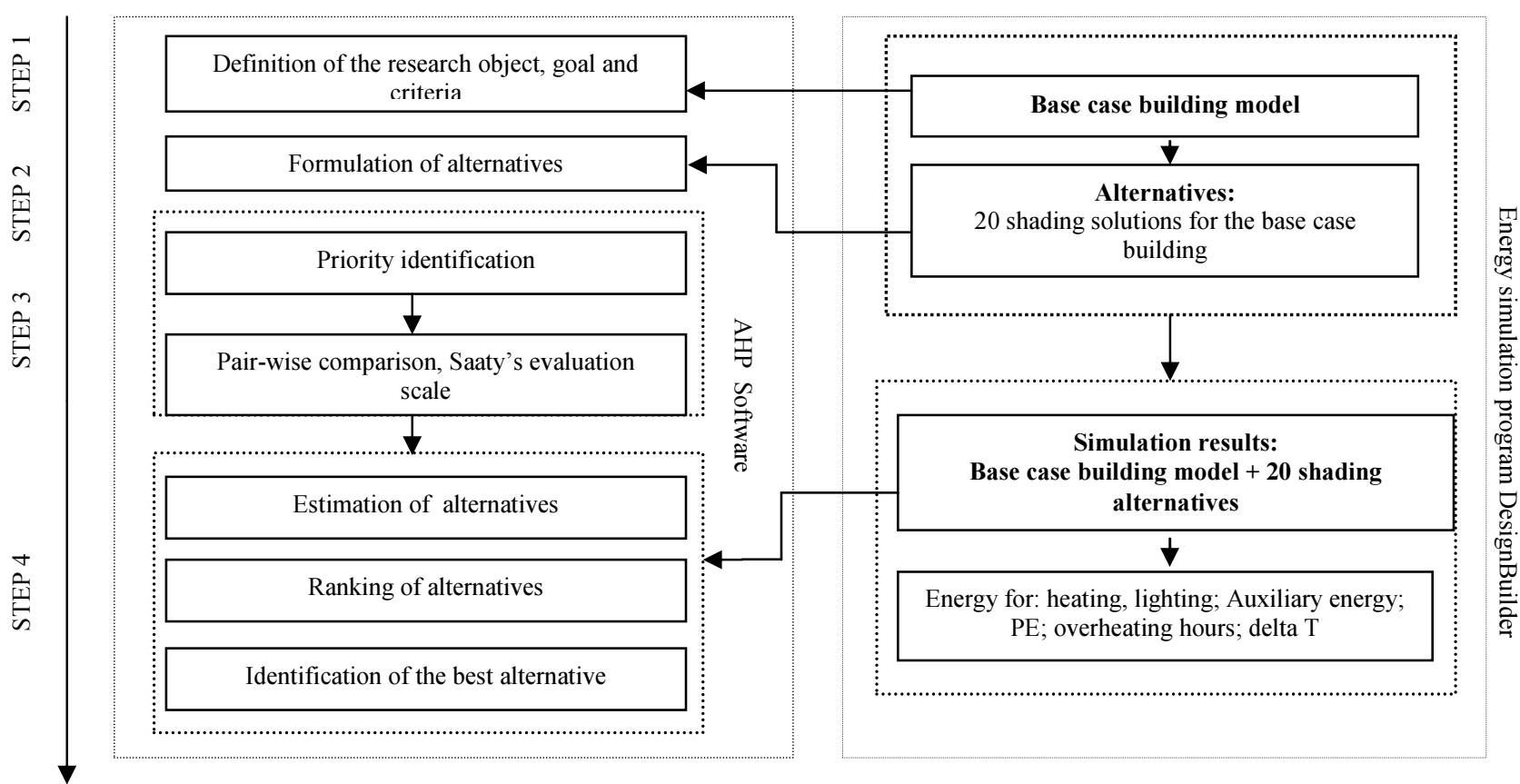

Fig. 1. The flowchart of the multi-criteria decision making process

Step 1 indicates the research object, goal, main criteria and subcriteria. The research object here is standard family house in Lithuania, there the focus is paid to building's energy efficiency and indoor comfort. The determined subcriteria for energy are: energy for heating, lighting, auxiliary energy and primary energy (PE). Comfort is specified in terms of Delta T and overheating hours. Delta $\mathrm{T}$ is the difference between maximum set temperature (here assumed $26^{\circ} \mathrm{C}$ ) and maximum average building temperature of the building reached during the summer. Overheating hours represent annual cooling energy demand and delta $\mathrm{T}$ - cooling load needed.

Step 2 includes the formulation of the alternatives. Here 20 alternatives - different shading solutions - for a base case building model are created in DesignBuilder.

Step 3 presents the prioritization of the criteria/subcriteria, using pair-wise comparison with Saaty's evaluation scale (Table 1). This can be done manually or using the decision-making software, based on Analytic Hierarchy Process.

Table 1. Evaluation scale used in pair - wise comparisons

\begin{tabular}{lll}
\hline Intensity of importance & Definition & Explanation \\
\hline 1 & Equal Importance & Two activities contribute equally to the objective \\
3 & Moderate importance & Experience and judgment slightly favour one activity over another \\
5 & Much more important & Experience and judgment strongly favour one activity over another \\
7 & Very strong or demonstrated importance & $\begin{array}{l}\text { An activity is favoured very strongly over another; its dominance } \\
\text { demonstrated in practice }\end{array}$ \\
9 & Extreme importance & $\begin{array}{l}\text { The evidence favouring one activity over another is of the highest possible } \\
\text { order of affirmation } \\
2,4,6,8\end{array}$ \\
\hline
\end{tabular}


The AHP is a theory of measurement through pair-wise comparisons and relies on the judgments of experts to derive priority scales. It is these scales that measure intangibles in relative terms. The comparisons are made using a scale of absolute judgments that represents, how much more, one element dominates another with respect to a given attribute [15].

To considered the pair-wise comparison matrix to be consistent enough, the consistence ratio (CR) have to be evaluated and satisfy the condition $\mathrm{CR}<0,1$.

Step 4 is carried out using DesignBuilder simulation results and software for decision making. Already having the prioritization of criteria (Step 3), the simulation results from DesignBuilder, the software scores the alternatives. As the result, the ranking of the shading solution (alternatives) or the best alternative can be obtained.

Hierarchical structure of the research is presented in Fig. 2.

FOCUS:

CRITERIA:

SUBCRITERIA: and

ALTERNATIVES:

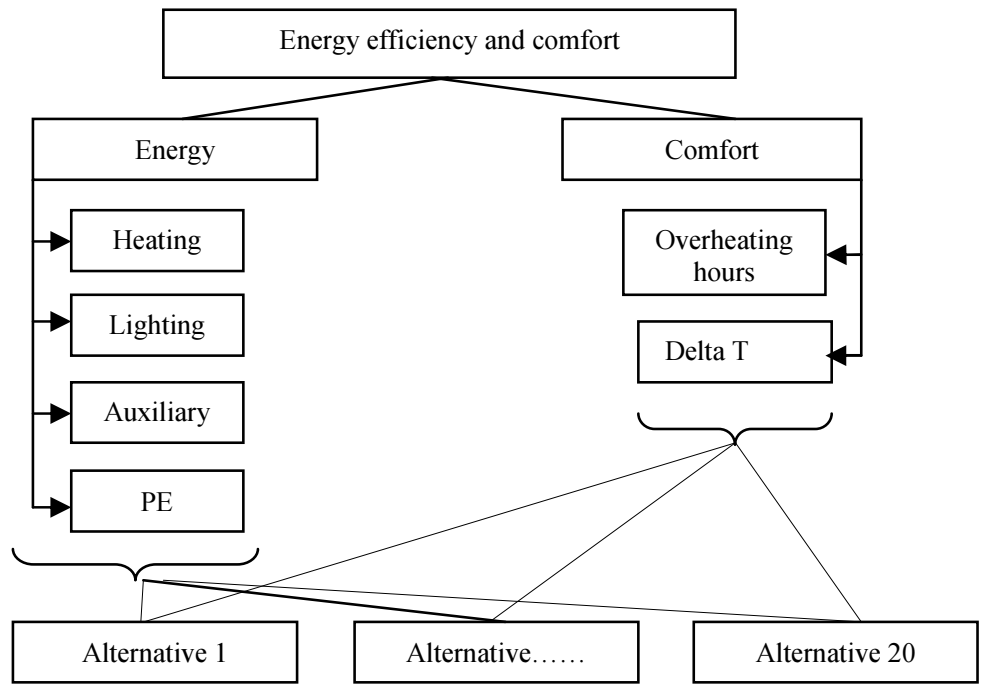

Fig. 2. Hierarchical structure of the research

\section{Case study}

With a purpose to analyse the performance of various solar shading measures, building model, described below, was created and simulated in DesignBuilder (Fig. 3).

Geometry. One-storey, square-shaped house was selected as an object for the analysis. The total area of the analysed building $-81 \mathrm{~m}^{2}$. Building is designed for standard family of 4 persons. Other characteristics of the envelope are supplied in Table 2 .

Lighting and electrical installations. LED lighting with a specific lamp power of $3 \mathrm{~W} / \mathrm{m}^{2} / 100$ lx is assumed to be installed. Lighting levels in premises correspond to the requirements of national regulations. It was assumed that lighting system operates when occupants are active. Lighting levels correspond to the national regulations [16]: bathroom - 75 lx, bedrooms - $200 \mathrm{~lx}$, living room and kitchen - $300 \mathrm{~lx}$, hall - $100 \mathrm{~lx}$.

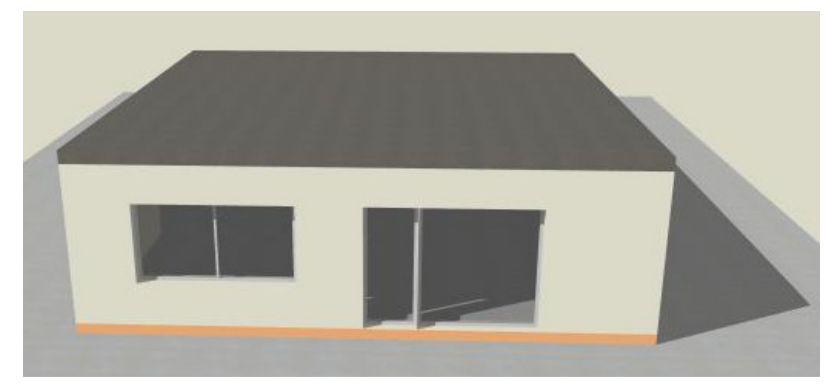

(a)

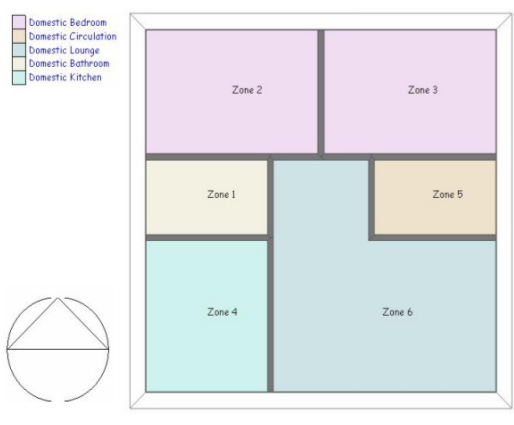

(b)

Fig. 3. Plan (a) and south façade (b) of the analysed building model

Ventilation. Mechanical constant air flow ventilation system with heat recovery unit and recirculation was designed in the building. Fresh air flow rates were selected according to the requirements of national standards. It was assumed that fresh air was supplied during the hours when building was occupied and one hour before the occupants came back home. During unoccupied hours the system is operated in recirculation mode. The total fresh air change rate in the building $0.6 \mathrm{~h}^{-1}$. 
Heating. Energy for heating is produced by gas boiler and water heating system is assumed to be installed. The comfort temperature of $20^{\circ} \mathrm{C}$ in all rooms, except bathroom, is maintained just during the occupancy hours. In the bathrooms temperature is $21^{\circ} \mathrm{C}$. For unoccupied periods heating set back temperature was set $2{ }^{\circ} \mathrm{C}$ lower than comfort temperatures. This heating strategy was defined as the most energy efficient.

Table 2. Thermal characteristics of the building envelope [17]

\begin{tabular}{ll}
\hline Building system & Description \\
\hline Exterior wall & $\mathrm{U}=0.11 \mathrm{~W} / \mathrm{m}^{2} \mathrm{~K}$. \\
\hline Roof & $\mathrm{U}=0.10 \mathrm{~W} / \mathrm{m}^{2} \mathrm{~K}$. \\
\hline Floor on the ground & $\mathrm{U}=0.15 \mathrm{~W} / \mathrm{m}^{2} \mathrm{~K}$. \\
\hline Windows & Triple glazed windows: $\mathrm{U}_{\text {glass }}=0.72 \mathrm{~W} / \mathrm{m}^{2} \mathrm{~K} ;$ \\
& $\mathrm{U}_{\text {frame }}=0.94 \mathrm{~W} / \mathrm{m}^{2} \mathrm{~K}$. \\
\hline Doors & Internal door $-\mathrm{U}=2.5 \mathrm{~W} / \mathrm{m}^{2} \mathrm{~K}$. \\
\cline { 2 - 2 } & External door $-\mathrm{U}=0.75 \mathrm{~W} / \mathrm{m}^{2} \mathrm{~K}$. \\
\hline
\end{tabular}

20 shading solutions (alternatives) for presented base case building model have been simulated in DesignBuilder. The description of solar shading alternatives is presented in Table 3.

Table 3. The description of alternatives

\begin{tabular}{|c|c|}
\hline Alternatives & Description \\
\hline Base case & No shading. No active cooling. \\
\hline A1 & $3 \mathrm{~m}$ depth roofing attached on the Southern façade. \\
\hline A3 & $3 \mathrm{~m}$ depth roofing and one $3 \mathrm{~m}$ depth side wall attached on the South façade \\
\hline A4 & $1 \mathrm{~m}$ depth roofing and one $1 \mathrm{~m}$ depth side walls attached on the South façade \\
\hline A5 & $\begin{array}{l}\text { External blinds with high reflectivity slats, blinds are on when room temperature reaches } 22{ }^{\circ} \mathrm{C} \text {, blinds are not applied during the heating } \\
\text { season. }\end{array}$ \\
\hline A6 & $\begin{array}{l}\text { External blinds with high reflectivity slats, blinds are on when room temperature reaches } 24{ }^{\circ} \mathrm{C} \text {, blinds are not applied during the heating } \\
\text { season. }\end{array}$ \\
\hline A7 & $\begin{array}{l}\text { External blinds with high reflectivity slats, blinds are on when room temperature reaches } 26^{\circ} \mathrm{C} \text {, blinds are not applied during the heating } \\
\text { season. }\end{array}$ \\
\hline A8 & External blinds with high reflectivity slats, operated according to set radiance level $120 \mathrm{~W} / \mathrm{m}^{2}$ all over the year. \\
\hline A9 & External blinds with high reflectivity slats, operated according to set radiance level $150 \mathrm{~W} / \mathrm{m}^{2}$ all over the year. \\
\hline A11 & $\begin{array}{l}\text { External blinds with high reflectivity slats, operated according to set radiance level } 120 \mathrm{~W} / \mathrm{m}^{2} \text { just when cooling is needed and also during } \\
\text { the night }\end{array}$ \\
\hline A12 & External blinds with high reflectivity slats, operated according to glare all over the year. \\
\hline A13 & $\begin{array}{l}\text { Internal blinds with high reflectivity slats, blinds are one when room temperature reaches } 22{ }^{\circ} \mathrm{C} \text {, blinds are not applied during the heating } \\
\text { season. }\end{array}$ \\
\hline A14 & $\begin{array}{l}\text { Internal blinds with high reflectivity slats, blinds are one when room temperature reaches } 24{ }^{\circ} \mathrm{C} \text {, blinds are not applied during the heating } \\
\text { season. }\end{array}$ \\
\hline A15 & $\begin{array}{l}\text { Internal blinds with high reflectivity slats, blinds are one when room temperature reaches } 26^{\circ} \mathrm{C} \text {, blinds are not applied during the heating } \\
\text { season. }\end{array}$ \\
\hline A16 & Drapes, open weave, light. Always on. \\
\hline A17 & $1 \mathrm{~m}$ overhangs. \\
\hline A18 & $1,5 \mathrm{~m}$ overhangs. \\
\hline A19 & $0,2 \mathrm{~m}$ projection wooden louvers. Louvers angle $-15^{\circ}$ \\
\hline A20 & $0,2 \mathrm{~m}$ projection wooden louvers. Louvers angle $-30^{\circ}$ \\
\hline
\end{tabular}

\section{Results}

\subsection{Priority identification}

3 experts have participated in the survey, in order to set the relevance of criteria (weights) and determine their priority. Such a number of experts have been selected to align different goals, but not to complicate the decision making process. Experts had to fill the pair-wise comparison matrix, where the subcriteria had further abbreviation: $x_{1}-$ Energy for heating; $x_{2}-$ Energy for lighting; $\mathrm{x}_{3}-$ Auxiliary energy; $\mathrm{x}_{4}-\mathrm{PE} ; \mathrm{x}_{5}$ - Overheating hours; $\mathrm{x}_{6}-$ DeltaT. For example, Table 4 presents the pair-wise comparison matrix, filled by the first expert. 
Table 4. Pair-wise comparison matrix of the first expert

\begin{tabular}{lrrrrrr}
\hline & $\mathrm{x}_{1}$ & $\mathrm{x}_{2}$ & $\mathrm{x}_{3}$ & $\mathrm{x}_{4}$ & $\mathrm{x}_{5}$ & $\mathrm{x}_{6}$ \\
\hline $\mathrm{x}_{1}$ & 1 & 1 & 1 & 0.2 & 0.2 & \\
$\mathrm{x}_{2}$ & 1 & 1 & 1 & 0.2 & 0.2 & 3 \\
$\mathrm{x}_{3}$ & 1 & 1 & 1 & 0.2 & 0.2 & 3 \\
$\mathrm{x}_{4}$ & 5 & 5 & 5 & 1 & 1 & 8 \\
$\mathrm{x}_{5}$ & 5 & 5 & 5 & 1 & 1 & 8 \\
$\mathrm{x}_{6}$ & 0.33 & 0.33 & 0.33 & 0.125 & 0.125 & 1 \\
\hline
\end{tabular}

$\mathrm{CR}=0.011<0.1$

The opinion of the rest experts is presented and generalized as group opinion in Table 5. It contains the evaluated criteria weights, their priority and the value of the consistence ratio (CR).

Table 5. The individual and generalized survey results

\begin{tabular}{lcccccccc}
\hline & \multicolumn{2}{c}{ Expert I } & \multicolumn{2}{c}{ Expert II } & \multicolumn{2}{c}{ Expert III } & \multicolumn{2}{c}{ Group } \\
\hline & Weights & Priority & Weights & Priority & Weights & Priority & Weights & Priority \\
$\mathbf{x}_{\mathbf{1}}$ & 0.8 & $3-5$ & 0.41 & 1 & 0.17 & 2 & 0.2 & 2 \\
$\mathbf{x}_{\mathbf{2}}$ & 0.08 & $3-5$ & 0.08 & 4 & 0.08 & $3-4$ & 0.09 & 4 \\
$\mathbf{x}_{\mathbf{3}}$ & 0.08 & $3-5$ & 0.04 & $5-6$ & 0.08 & $3-4$ & 0.07 & 5 \\
$\mathbf{x}_{\mathbf{4}}$ & 0.36 & $1-2$ & 0.29 & 2 & 0.54 & 1 & 0.43 & 1 \\
$\mathbf{x}_{\mathbf{5}}$ & 0.36 & $1-2$ & 0.14 & 3 & 0.07 & 5 & 0.16 & 3 \\
$\mathbf{x}_{\mathbf{6}}$ & 0.03 & 6 & 0.04 & $5-6$ & 0.06 & 6 & 0.05 & 6 \\
\hline \multicolumn{6}{c}{$\mathrm{CR}=0.01<0.1$} & $\mathrm{CR}=0.03<0.1$ & $\mathrm{CR}=0.04<0.1$ &
\end{tabular}

The generalized results have showed, that the criteria weights after the pair-wise comparison are: PE (0.43), Energy for heating (0.2), Overheating hours (0.16), Energy for lighting (0.09), Auxiliary energy (0.07) and Delta T (0.05).

So the priority of criteria are as follows: $\mathbf{x}_{\mathbf{4}}(\mathrm{PE})>\mathbf{x}_{\mathbf{1}}$ (Energy for heating) $>\mathbf{x}_{\mathbf{5}}$ (Overheating hours) $>\mathbf{x}_{\mathbf{2}}($ Energy for lighting $)>\mathbf{x}_{\mathbf{3}}$ (Auxiliary energy) $>\mathbf{x}_{\mathbf{6}}($ Delta $\mathrm{T})$.

\subsection{Ranking the alternatives}

Energy and comfort simulation results from DesignBuilder for base case model and its 20 alternatives are shown in Fig. 4.

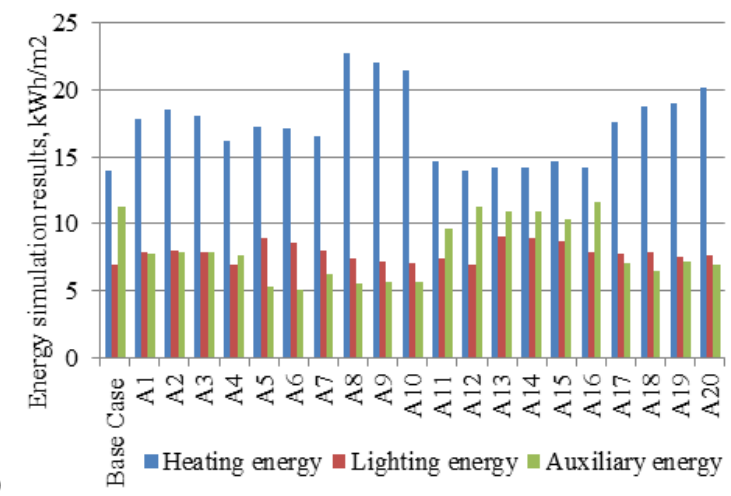

a)

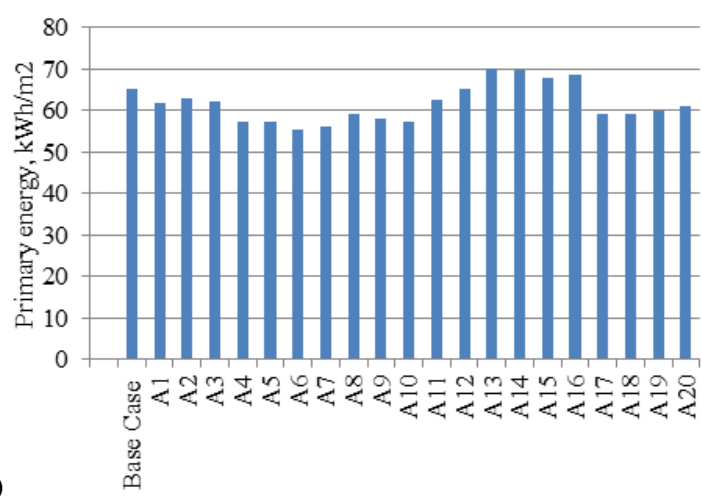

c)

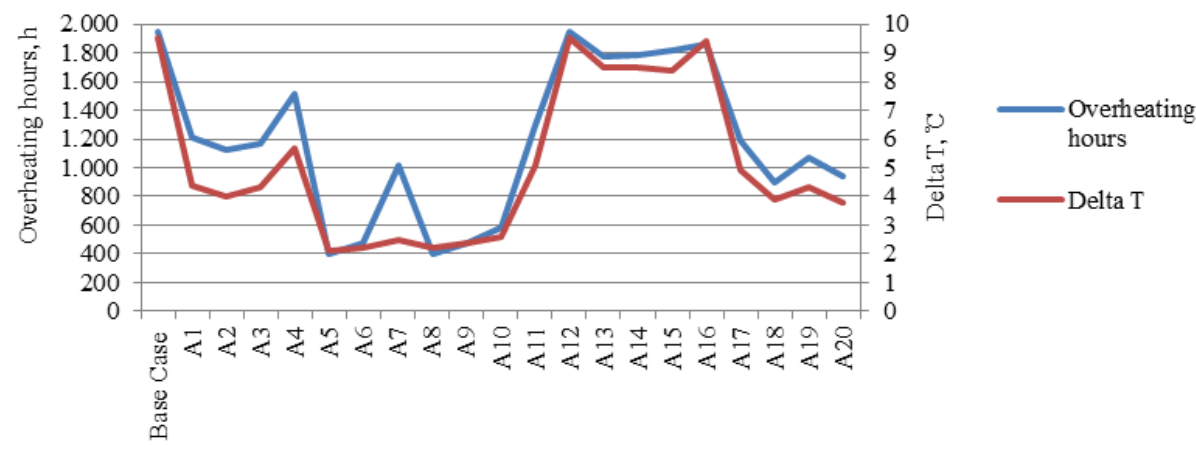

Fig. 4. The energy ( $a, b)$ and comfort (c) performance for different shading alternatives 
Alternatives A5, A6, A7 and A8 seem to have the lowest PE consumption, smallest amount of discomfort hours and Delta $T$ values, excluding energy for heating. Even so, simulation results are conflicting: if A5 alternative has smaller amount of discomfort hours and Delta values than A6 alternative, at the same time A5 has higher energy consumption. That is why, appear some difficulties to pick out the best alternative.

A decision-making software, based on Analytic Hierarchy Process have been used, in order to rank all the shading alternatives according to the criteria priority (Fig. 5). It also demonstrates the criteria proportions in every alternative.

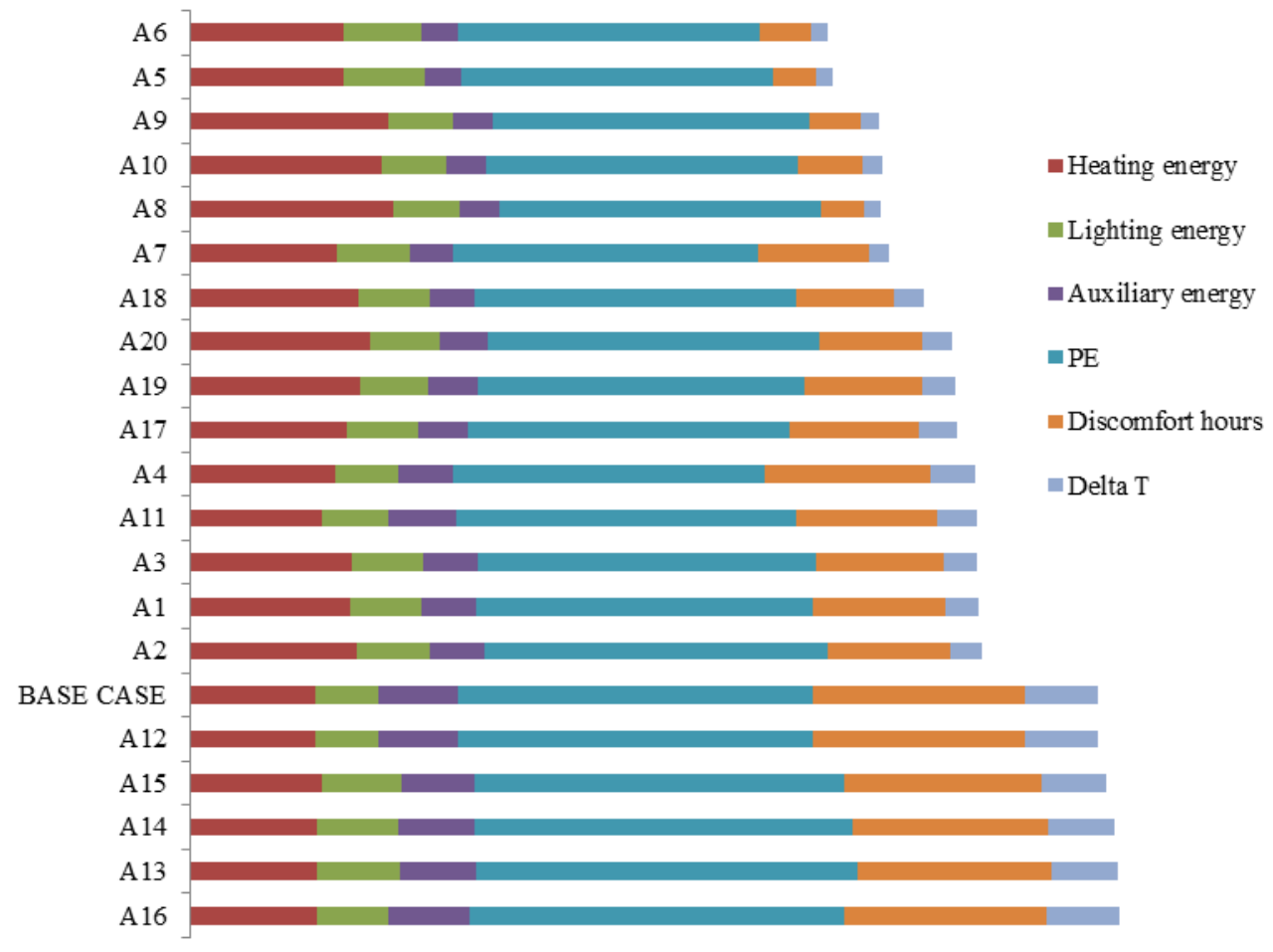

Fig. 5. The final ranking of the alternatives

Table 6 presents the description of five best alternatives. The best/optimal alternative "A6" - is the building model, with external blinds with high reflectivity slats, blinds are on when room temperature reaches $24^{\circ} \mathrm{C}$ and blinds are not applied during the heating season.

Table 6. The rank of five best alternatives

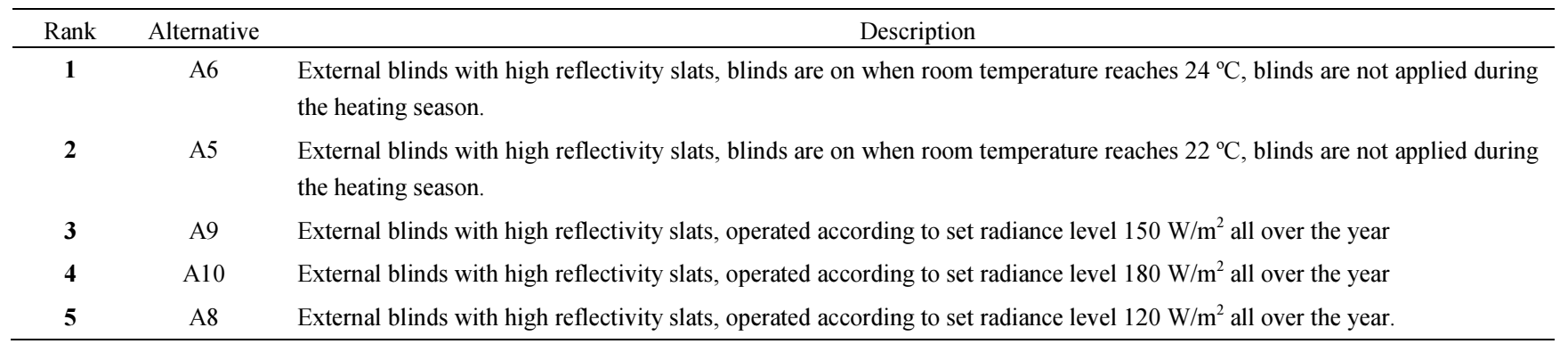

According to the results, the most effective shading solutions are the external blinds with high reflectivity, which are on when the indoor temperature set point derive from $22-24^{\circ} \mathrm{C}$. The first and second best alternatives are very close to each other. This could be seen even before the AHP, but it was difficult to rank them correctly, as their subcriteria values were similar.

External blinds, which operate according to set radiance level from $180-120 \mathrm{~W} / \mathrm{m}^{2}$ all over the year, have $3^{\text {rd }}-5^{\text {th }}$ rank. The least effective are external, open weave, blinds (A16). They create quite small heating energy consumption, but have the highest auxiliary energy consumption and stand out with other parameters.

\section{Discussion}

In this case, some of the best shading alternatives could be foreseen even before the decision making process. This is because the determined criteria weights for PE and discomfort hours were one of the most relevant, while at the same time, the first two best alternatives had rather low values of these criteria. Hence, more conflicting expert's criteria ranking could 
turn upside down the ranking positions. For example, if the main goal would be to design building which can be certified as passive house, then heating demand criteria would get much higher priority and the results concerning optimal solution would change dramatically.

The results could be also markedly different, if more criteria would be involved: the price for shading solutions or the cost for overall building construction. The most effective automated external shading devices are the most expensive, so the first alternative would have to vary between these criteria. The methodology and instruments, presented in this article for alternative ranking, could be adapted even under exchanging, criteria, their quantity or experts view.

\section{Conclusions}

Comparing all the shading alternatives, it is obvious, that different shading make manifold impact on energy demand and comfort criteria. The automated shading devices, which operate according to the set point temperature or radiance level, are more effective to decrease the amount of solar gains, than non-controlled ones. But the decreased amount of daylight, negatively affects visual comfort and lighting energy consumption. During the heating season, the additional heat from solar gains decrease the heating demand and application of shading stops this beneficial heat. That is why, the optimal shading solution according to local conditions and individual priorities should be designed.

In presented case study, 3 experts have been involved in the decision making process, in order to determine the criteria priority. Primary energy has been elected as the most relevant criterion. The final ranking has showed that automated external blinds, which were applied according to the room's set point temperature $-24{ }^{\circ} \mathrm{C}$ is the optimal solution.

\section{Acknowledgements}

This research was funded by a grant (No. ATE-03/2012) from the Research Council of Lithuania.

\section{References}

[1] Directive 2010/31/EU of the European Parliament and of the council of 19 May 2010 on the energy performance of buildings (recast). Off J Eur Union 2010. L 153/13-L 153-35

[2] Kolokotsa, D.; Diakaki, C.; Grigoroudis, E.; Stavrakakis, G.; Kalaitzakis, K. 2009. Decision support methodologies on the energy efficiency and energy management in buildings, Advanced Building Energy Research 3(1): 121-146. http://dx.doi.org/10.3763/aber.2009.0305

[3] Tzempelikos, A. K.; Athienitis, A.; Karava, P. 2007. Simulation of façade and envelope design options for a new institutional building, Solar Energy 81(9): 1088-1103. http://dx.doi.org/10.1016/j.solener.2007.02.006

[4] Sadineni, S. B.; Madala, S.; Boehm, R. F. 2011. Passive building energy savings: A review of building envelope components, Renewable and Sustainable Energy Reviews 15(8): 3617-3631. http://dx.doi.org/10.1016/j.rser.2011.07.014

[5] Capeluto, I. G. 2003. Energy performance of the self-shading building envelope, Energy and Buildings 35(3): 327-336. http://dx.doi.org/10.1016/S0378-7788(02)00105-6

[6] Aoletti, G. P.; Vesani, S. A.; Xner, D. E.; Lollini, R. 2011. Designing low energy buildings : application of a parametric tool and case studies, in Proc. of the 27th International Conference on Passive and Low Energy Architecture - Louvain La Neuve, Belgium. 2011. 13-15 July 2011

[7] Diakaki, C.;Grigoroudis, E.; Kabelis, N.; Kolokotsa, D.; Kalaitzakis, K.; Stavrakakis, G. 2010. A multi-objective decision model for the improvement of energy efficiency in buildings, Energy 35(12): 5483-5496. http://dx.doi.org/10.1016/j.energy.2010.05.012

[8] Mela, K.; Tiainen, T.;Heinisuo, M. 2012. Comparative study of multiple criteria decision making methods for building design, Advanced Engineering Informatics 26(4): 716-726. http://dx.doi.org/10.1016/j.aei.2012.03.001

[9] Manzan, M.; Pinto, F. 2009. Genetic optimization of external shading devices, in Proc. oh the 11th International IBPSA Conference of Building Simulation. Glasgow, Scotland, 2009.

[10] Machairas, V.; Tsangrassoulis, A.; Axarli, K. 2014. Algorithms for optimization of building design: A review, Renewable and Sustainable Energy Reviews 31(1364): 101-112. http://dx.doi.org/10.1016/j.rser.2013.11.036

[11] Shi, X. 2011. Design optimization of insulation usage and space conditioning load using energy simulation and genetic algorithm, Energy 36(3): 1659-1667. http://dx.doi.org/10.1016/j.energy.2010.12.064

[12] Cabala, P. 2010. Using the analytic hierarchy process. General Characteristics of the Method, Operations research and decision 1(1): $5-23$.

[13] Zavadskas, E. K.; Medineckiene, M.; Turskis, Z. 2011. Life - cycle analysis of a sustainable building, aplying multi-criteria decision making method, in Proc. oh the 8th International Conference Environmental Engineering. Vilnius, Lithuania, 2011. Vilnius: Technika, 957-961.

[14]Decision making software tool ,,Make it Rational". Available at: http://makeitrational.com/

[15] Saaty, T. L. 2008. Decision making with the analytic hierarchy process, International Journal of Services Systems 1(1): 83-98. http://dx.doi.org/10.1504/IJSSCI.2008.017590

[16]STR 2.02.09:2005 Vienbučiai ir dvibučiai gyvenamieji pastatai. [Single-family and double-family buildings] Vilnius: Lithuanian Ministry of Environment, 2005, 19 p.

[17]Motuziene, V. ; Vilutiené, T. 2013. Modelling the effect of the domestic occupancy profiles on predicted energy demand of the energy efficient house, in Procedia Engineering. 11th international conference on modern building materials, structures and techniques (MBMST), May 16-17, 2013, Vilnius, Lithuania. Amsterdam : Elsevier Science Ltd, (57): 798-807. ISSN $1877-7058$. 